\title{
PRESUPPOSITION OF PRESIDENT ERDOGAN'S MESSAGE IN HUMAN RIGHTS DAY ON DECEMBER 10, 2018
}

\author{
Ratu Nur Auliawanti ${ }^{1}$, Aseptiana Parmawati ${ }^{2}$ \\ ${ }^{1}$ IKIP Siliwangi \\ ${ }^{2}$ IKIP Siliwangi \\ ${ }^{1}$ ratunurauliawanti@ student.ikipsiliwangi.ac.id, ${ }^{2}$ aseptiana@ikipsiliwangi.ac.id
}

\begin{abstract}
Communication will be impossible if everything had to be defined or explained every time we spoke. Whatever a speaker or writer assume that the receiver of the message already knows is called presupposition. This research analyzed about presupposition of message Recep Tayyip Erdoğan as President of The Republic of Turkey on Human Rights Day, December 10, 2018. The aims of this research are to find out the types of presupposition and identify the most dominant type of presupposition that used by Erdogan. Classification about types of presupposition by Yule (1996) as cited in Tryana \& Satelah (2018) used in this research. The researchers analyzed the data with some steps applying the qualitative method, the researchers identifying the scripts of the speech, classifying the utterances into presupposition and categorizing them based on the types of presupposition. After that, counting the types of presupposition in percentage. As the result, The existential presupposition is the dominant type in Erdogan's speech with the percentage 56,67\% and followed by lexical and factive in the second and third position.
\end{abstract}

Keywords: Presupposition, Types of Presupposition, Recep Tayyip Erdoğan

\section{INTRODUCTION}

Language is a primary tool for human to communicate in social life, because there is no society without communication. It is in line with opinion from KLM (2018), to communicate with others in their life, wether they talk, argue, or make opinion, people needs a system which called language. Based on Sukmawati, S \& Wijayanto (2020), communication is the process of sending and receiving messages through verbal or nonverbal means, including speech, or oral communication; writing and graphical representation (such as infographics, maps, and charts); signs, signals, and behavior. Hybel \& Weaver (2004) in Indah et.al (2018) in Viahapsari and Parmawati (2020) who defined communication as an interaction process between one person to another which aimed to the information and beliefs, swap ideas, making plan and solve the problem. In order to be successful in communication, all participants must understand what the context in their conversation because when the communication between two people or more or speakers and listeners take place, sometimes the speaker assumption is implicit and confusing. To understand the utterance of the speaker, the listener must consider with the context in which the speaker uses the utterances. The importance of understanding the context will be in the use of speech which has hidden meaning by the speakers (Astuti et al., 2019). For that reasons, to know the one what is communicated, but not said, we must to know about pragmatics and presupposition first. According to Tang (2019), presupposition is part of linguists from semantics and pragmatics perspective.

Pragmatics is the study of language which addresses the true meaning of a word (Kuswandi \& Apsari, 2019), while presupposition is something the speaker assumed to be case prior of making utterance (Yule, 1996) as cited in (Sukmawati, S \& Wijayanto, 2020). In the other 
source, presupposition is like the truly background of the speaker's statement (Stalnaker, 1974) as cited in (Arkasa, 2019). Researcher can be conclude that presupposition is the information that speaker assumes to be already known but unsaid.

This research investigated the presupposition in the speech of Recep Tayyip Erdoğan, Presidency of Republic Turkey about his message on Human Rights Day. The aim of this research is to find out the types of presupposition and and identify the dominant type of presupposition.

The scope of the study of pragmatics is very broad so the writer limits it on presupposition types by Yule (1996) as cited in Tryana \& Satelah (2018), namely: existential, factive, lexical, structural, non-factive, and counterfactual presuppositions. Whereas:

(1) Existential presupposition is commited to the existence of the entities named or deliver something tha exist. For example, my mother has a new car. It means, my mother is exist and the car is exist.

(2) Factive presupposition, since some words/verbs/construction indicate that something is a fact. Sush as know, glade, realize, regret, odd, aware, and etc. For example, I'm glade its over. It means, that is truly over.

(3) Lexical presupposition, when the speaker using one word can act as if another meaning will be understand, such as stop, start, again. For example, you are late again. It means, you were late before.

(4) Structural presupposition. It is the assumption associated with the use of certain structures. Such as wh- forms can be used in this type. For example, where did you buy the book? It presupposes that speaker knows that "you" bought the book.

(5) Non-factive presupposition. It is an assumption referred to something that is not true. There are verb as a signal if that is not true, such as dreamed, imagine, etc. for example, they dreamed that they were rich. It means, they were not rich.

(6) Counterfactual presupposition. It is the assumption that what is presupposed is not only untrue but is the opposite of what is true or contrary to facts. For example, if I were rich, I would buy a Ferrari. It presupposed that I am not rich and not buying Ferrari.

\section{METHOD}

This research employed qualitative descriptive method as the research methodology. In qualitative descriptive method, words or sentences more used rather than numbers to explain and describe of the case (Riana, et al., 2019). Based on Basrowi \& Suwandi (2008) as cited in Astuti et al (2019), qualitative research data refers to the rich of words, pictures, figures. It means, the researcher analyzed the data descriptively and the presentation of the result was in a form of explanation of words which would be supported by the data presented.

By using this qualitative method, the researchers will explain and describe about Erdogan's presuppositions in his speech about the message on Human Rights Day on December $10^{\text {th }}, 2018$. After collecting the data, the researchers analyzed the data with some steps applying the qualitative method, the researchers identifying the scripts of the speech, classifying the utterances into presupposition and categorizing them based on the types of presupposition. After that, counting the types of presupposition in percentage by using this formula:

FK rel $=\frac{\text { FK }}{\sum F} \times 100 \%$ 
FK rel : Frequency of relative cumulative (Percentage of types)

FK : Frequency of cumulative (total types frequency of sub-category)

$\sum \mathrm{F} \quad$ : Frequency of total (total of all categories)

$100 \%$ : Percentage

\section{RESULTS AND DISCUSSION}

\section{Results}

The data analysis of presupposition were grouped based on the theory of Yule (1996) as cited in Tryana \& Satelah (2018), in which the presupposition appeared from the presupposition triggers. The data were identified into presuppositions by underlining the triggers of presupposition in utterances. The presupposition in every utterance is written based on the triggers.

\section{Table 1}

The presuppositions applied in Erdogan's message in Human Rights Day address on December 10, 2018.

\begin{tabular}{|c|c|c|c|c|c|c|c|c|}
\hline \multirow{2}{*}{ NO. } & \multirow{2}{*}{ Sentence } & \multirow{2}{*}{ Possible Presupposition } & \multicolumn{6}{|c|}{ Types of Presupposition } \\
\hline & & & $\mathbf{E P}$ & $\mathbf{F P}$ & $\mathbf{L P}$ & SP & NP & $\mathbf{C P}$ \\
\hline 1. & $\begin{array}{l}\text { I celebrate the Human } \\
\text { Rights Day of my citizens } \\
\text { and the whole world. }\end{array}$ & $\begin{array}{l}\text { >> citizens and the } \\
\text { whole world exist.. }\end{array}$ & $\sqrt{ }$ & & & & & \\
\hline 2. & $\begin{array}{l}\text { The occasion of the } 70^{\text {th }} \\
\text { anniversary of the } \\
\text { adoption of the United } \\
\text { Nations Universal } \\
\text { Declaration of Human } \\
\text { Rights. }\end{array}$ & $\begin{array}{l}\text { >> declaration of Human } \\
\text { Rights exists. }\end{array}$ & $\sqrt{ }$ & & & & & \\
\hline 3. & $\begin{array}{l}\text { We welcome another } \\
\text { Human Rights Day at a } \\
\text { time regrettably. }\end{array}$ & $\begin{array}{l}\text { >> Human Rights Day } \\
\text { have been held before. }\end{array}$ & & & $\sqrt{ }$ & & & \\
\hline 4. & $\begin{array}{l}\text { When the most } \\
\text { fundamental human } \\
\text { rights, including the right } \\
\text { to life. }\end{array}$ & $\begin{array}{l}\text { > there is a lot of } \\
\text { aspects in fundamental } \\
\text { human rights, not just } \\
\text { the right to life. }\end{array}$ & & & $\sqrt{ }$ & & & \\
\hline 5. & $\begin{array}{l}\text { Continue to be violated in } \\
\text { the regions close to our } \\
\text { hearts, from Syria to Iraq, } \\
\text { from Arakan to Palestine. }\end{array}$ & $\begin{array}{l}>>\text { there is a violating } \\
\text { before. }\end{array}$ & & & $\sqrt{ }$ & & & \\
\hline 6. & $\begin{array}{l}\text { The hundreds of } \\
\text { thousands of children in } \\
\text { Yemen are falling victim } \\
\text { to conflicts of interest. }\end{array}$ & $\begin{array}{l}\text { > children in Yemen } \\
\text { are falling victim to } \\
\text { conflicts is exist. }\end{array}$ & $\sqrt{ }$ & & & & & \\
\hline 7. & $\begin{array}{l}\text { This shameful image in } \\
\text { the name of humanity. }\end{array}$ & $\begin{array}{l}>>\text { humanity is in the } \\
\text { shame situation. }\end{array}$ & & $\sqrt{ }$ & & & & \\
\hline
\end{tabular}




\begin{tabular}{|c|c|c|c|c|}
\hline 8. & $\begin{array}{l}\text { The international } \\
\text { community still has a } \\
\text { long way to go. }\end{array}$ & $\begin{array}{l}\text { >> the international } \\
\text { community has a long } \\
\text { way to go before and has } \\
\text { not changed. }\end{array}$ & & $\sqrt{ }$ \\
\hline 9. & $\begin{array}{l}\text { In upholding the } \\
\text { principles and } \\
\text { sensitivities set by the } \\
\text { Universal Declaration of } \\
\text { Human Rights. }\end{array}$ & $\begin{array}{l}\text { >> principles and } \\
\text { sensitivities of Human } \\
\text { Rights exist. }\end{array}$ & $\sqrt{ }$ & \\
\hline 10. & $\begin{array}{l}\text { The incompetence of } \\
\text { international mechanisms } \\
\text { responsible for ensuring } \\
\text { security, peace, and } \\
\text { stability throughout the } \\
\text { world }\end{array}$ & $\begin{array}{l}\text { >> international } \\
\text { mechanism responsible } \\
\text { exists. }\end{array}$ & $\sqrt{ }$ & \\
\hline 11. & $\begin{array}{l}\text { Such as the United } \\
\text { Nations Security Council, } \\
\text { is one of the most } \\
\text { important factors making } \\
\text { human rights violations } \\
\text { so common. }\end{array}$ & $\begin{array}{l}\text { >> there is another } \\
\text { important factor making } \\
\text { human rights violations } \\
\text { so common. }\end{array}$ & & $\sqrt{ }$ \\
\hline 12. & $\begin{array}{l}\text { Israel is able to recklessly } \\
\text { continue its policies of } \\
\text { occupation, deportation } \\
\text { and oppression in the } \\
\text { Palestinian territories. }\end{array}$ & $\begin{array}{l}\text { >> Israel was oppressed } \\
\text { to Palestine before. }\end{array}$ & & $\sqrt{ }$ \\
\hline 13. & $\begin{array}{l}\text { The mentality that puts } \\
\text { self-interest above human } \\
\text { life. }\end{array}$ & >> the mentality exists. & $\sqrt{ }$ & \\
\hline 14. & $\begin{array}{l}\text { That makes distinctions } \\
\text { between terrorist } \\
\text { organizations. }\end{array}$ & $\begin{array}{l}\text { > terrorist organization } \\
\text { exists. }\end{array}$ & $\sqrt{ }$ & \\
\hline 15. & $\begin{array}{l}\text { Its attitude depending on } \\
\text { the identity of the } \\
\text { oppressed or the } \\
\text { oppressor. }\end{array}$ & >> attitude exists & $\sqrt{ }$ & \\
\hline 16. & $\begin{array}{l}\text { Turkey has also } \\
\text { domestically put into } \\
\text { practice several } \\
\text { comprehensive reforms. }\end{array}$ & $\begin{array}{l}\text { > not put into all } \\
\text { practice comprehensive } \\
\text { reforms. }\end{array}$ & & $\sqrt{ }$ \\
\hline 17. & $\begin{array}{l}\text { In order to strengthen its } \\
\text { democracy. }\end{array}$ & >> democracy exist. & $\sqrt{ }$ & \\
\hline 18. & $\begin{array}{l}\text { The creation of the } \\
\text { Turkish Human Rights } \\
\text { and Equality Institution } \\
\text { and the Ombudsman } \\
\text { Institution. }\end{array}$ & $\begin{array}{l}\text { > Turkish Human } \\
\text { Rights, Equality } \\
\text { Institution, and } \\
\text { Ombudsman Institution } \\
\text { exist. }\end{array}$ & $\sqrt{ }$ & \\
\hline 19. & $\begin{array}{l}\text { The introduction of the } \\
\text { right to file an individual }\end{array}$ & $\begin{array}{l}>>\text { the right to file an } \\
\text { individual application }\end{array}$ & $\sqrt{ }$ & \\
\hline
\end{tabular}




\begin{tabular}{|c|c|c|c|c|}
\hline & $\begin{array}{l}\text { application to the } \\
\text { Constitutional Court }\end{array}$ & $\begin{array}{l}\text { and Constitutional Court } \\
\text { exist. }\end{array}$ & & \\
\hline 20. & $\begin{array}{l}\text { the removal of certain } \\
\text { bans }\end{array}$ & $\begin{array}{l}\text { > there is a category of } \\
\text { bans. }\end{array}$ & & $\sqrt{ }$ \\
\hline 21. & $\begin{array}{l}\text { were restricting the } \\
\text { fundamental rights and } \\
\text { freedoms of our citizens. }\end{array}$ & >> Citizens exist. & $\sqrt{ }$ & \\
\hline 22. & $\begin{array}{l}\text { only part of the } \\
\text { revolutionary steps that }\end{array}$ & $\begin{array}{l}\text { > refer to removal of } \\
\text { certain bans which not } \\
\text { part of another steps. }\end{array}$ & & $\sqrt{ }$ \\
\hline 23. & $\begin{array}{l}\text { have been taken in the } \\
\text { last sixteen years. }\end{array}$ & $\begin{array}{l}\text { > before the last sixteen } \\
\text { years, its never be taken. }\end{array}$ & & $\sqrt{ }$ \\
\hline 24. & $\begin{array}{l}\text { With the inception of the } \\
\text { implementation of the } \\
\text { Presidential Government } \\
\text { System. }\end{array}$ & $\begin{array}{l}\text { >> Presidential } \\
\text { Government System } \\
\text { exists. }\end{array}$ & $\sqrt{ }$ & \\
\hline 25. & $\begin{array}{l}\text { our country's will and } \\
\text { determination for reform } \\
\text { has been further } \\
\text { strengthened. }\end{array}$ & $\begin{array}{l}\text { >> country exists. } \\
\text { >> the country has not } \\
\text { determination for reform } \\
\text { has been further } \\
\text { strengthened before. }\end{array}$ & $\sqrt{ }$ & $\sqrt{ }$ \\
\hline 26. & $\begin{array}{l}\text { Turkey in line with the } \\
\text { spirit of the Universal } \\
\text { Declaration of Human } \\
\underline{\text { Rights and inspired by its }} \\
\text { history and traditional } \\
\text { values, }\end{array}$ & $\begin{array}{l}\text { > there is spirit of the } \\
\text { Universal Declaration of } \\
\text { Human Rights. } \\
\text { >> history and } \\
\text { traditional values exit. }\end{array}$ & $\sqrt{ }$ & \\
\hline 27. & $\begin{array}{l}\text { Will continue to expand } \\
\text { the areas of freedom of its } \\
\text { citizens in the upcoming } \\
\text { period. }\end{array}$ & $\begin{array}{l}\text { >> there is an expand } \\
\text { areas of freedom before. } \\
\text { >> 'its' refer to the } \\
\text { citizens of the areas and } \\
\text { exists }\end{array}$ & $\sqrt{ }$ & $\sqrt{ }$ \\
\hline 28. & With these thoughts & $\begin{array}{l}>>\text { there are any } \\
\text { thoughts }\end{array}$ & $\sqrt{ }$ & \\
\hline 29. & $\begin{array}{l}\text { I would like to } \\
\text { congratulate once again } \\
\text { my citizens' Human } \\
\text { Rights Day }\end{array}$ & $\begin{array}{l}\text { > President Erdogan } \\
\text { have been said about that } \\
\text { before. }\end{array}$ & & $\sqrt{ }$ \\
\hline 30 & $\begin{array}{l}\text { hoping that it will } \\
\text { contribute to peace, } \\
\text { justice and serenity all } \\
\text { over the world }\end{array}$ & $\begin{array}{l}\text { > has not contribute } \\
\text { before. }\end{array}$ & & $\sqrt{ }$ \\
\hline
\end{tabular}


Table 2

The Percentage of Six Types of Presupposition in Erdogan's message in Human Rights Day

\begin{tabular}{llcc}
\hline NO. & \multicolumn{1}{c}{$\begin{array}{c}\text { Types of } \\
\text { Presupposition }\end{array}$} & $\begin{array}{c}\text { Number of } \\
\text { Presupposition }\end{array}$ & Percentage (\%) \\
\hline 1. & Existential & 17 & 56,67 \\
\hline 2. & Factive & 1 & 3,33 \\
\hline 3. & Lexical & 12 & 40 \\
\hline 4. & Structural & - & - \\
\hline 5. & Non-factive & - & - \\
\hline 6. & Counter-factual & - & - \\
\hline \multicolumn{5}{r}{ Total } & 30 & $100 \%$
\end{tabular}

\section{CONCLUSION}

From the data which analyzed in result and discussion, message from Erdogan in Human Rights Day on December 10, 2018 there are 30 utterances and have three types of presupposition namely Existential, Factive, and Lexical. The percentage of each type is 56,67\%, 3,33\%, and 40\%. The existential presupposition is the dominant type in Erdogan's speech with the percentage $56,67 \%$ because the speech contained about real facts and information about Human Rights nowadays. After that, followed by lexical and factive in the second and third position.

\section{ACKNOWLEDGMENTS}

Alhamdulillahi rabbil 'alamin, the researchers express the highest gratitude to Allah Subhanahu wa ta'ala for love, blessing, opportunity, health, and mercy to complete this article. In arranging this article, a lot of people have provided motivation, advice, and support for the researchers. First, the deepest appreciation goes to beloved parents for always praying for the successful article also for financial support. Second, this aricle would not have been possible without the advice, support, and patience of my advisor, Mrs. Aseptiana Parmawati, M.Pd and all of lecturers. The last, researchers very grateful to some close friends who always give the support, help, and good listener for every problem in arranging this article.

\section{REFERENCES}

Arkasa, N. R. S. (2019). Presupposition In Awkarin's Instagram Caption (Doctoral Dissertation, UIN Sunan Gunung Djati Bandung).

Astuti, R. W., Waluyo, H. J., \& Rohmadi, M. (2019). The Value Of Presuppositions In The Animated Film Nussa And Rara (A Study Of Pragmatics). In SEWORD FRESSH 2019: Proceedings Of The 1st Seminar And Workshop On Research Design, For Education, 
Social Science, Arts, And Humanities, SEWORD FRESSH 2019, April 27 2019, Surakarta, Central Java, Indonesia (P. 225). European Alliance For Innovation.

Klm, L. L. (2018). Presupposition Based On Ikea Catalogue 2017 Edition (Doctoral Dissertation, State Islamic University).

Kuswandi, M., \& Apsari, Y. (2019). An Analysis Of Pauses, Overlaps And Backchannels In Conversation In Vlog By Nessie Judge. Project (Professional Journal Of English Education), 2(3), 282-291.

Sukmawati, S., \& Wijayanto, A. (2020). Presupposition As Found In Wonder Woman Movie: A Pragmatics Analysis (Doctoral Dissertation, Universitas Muhammadiyah Surakarta).

Tambunan, A. R. S., Lubis, F. K., Purba, N., Girsang, M., \& Sembiring, E. M. B. (2019). Presupposition In "Barbie And The Magic Of Pegasus" Movie. Asian Themes In Social Sciences Research, 3(1), 18-21.

Tang, X. (2019, July). Pragmatic Presupposition And Its Function In Advertisements: A Case Study Of Lancôme. In 4th International Conference On Contemporary Education, Social Sciences And Humanities (ICCESSH 2019). Atlantis Press.

Tryana, T., \& Satelah, S. (2019, August). Presupposition Of Slogan In The Jakarta Post Advertisement. In PROCEEDINGS (Vol. 9, No. 1).

Viahapsari, E., \& Parmawati, A. (2020). Analysis The Type Of Deixis In The Main Character On The Movie I Leave My Heart In Lebanon. Project (Professional Journal Of English Education), 3(3), 388-394. 